\title{
Original
}

\section{Erdheim-Chester disease and pituitary involvement: a unique case and the literature}

\author{
Katsunori Manaka, Noriko Makita and Taroh Iiri
}

Department of Endocrinology and Nephrology, The University of Tokyo School of Medicine, Tokyo 113-8655 Japan

\begin{abstract}
An early thirties man diagnosed with Erdheim-Chester disease (ECD) was simultaneously disclosed to have hypogonadotropic hypogonadism, central adrenal insufficiency, and GH deficiency in addition to central diabetes insipidus (CDI). Pituitary magnetic resonance imaging (MRI) showed swelling in the stalk, enlargement of the anterior lobe with delayed enhancement, and loss of high intensity of the posterior lobe on T1-weighted images, suggesting of pituitary involvement of ECD. Three months after starting treatment with interferon $\alpha$ and zoledronic acid, polyuria and polydipsia were ameliorated without DDAVP, accompanied with improvement of MRI. Simultaneously technetium-99m bone scintigraphy showed improvement, accompanied with a relief of bone pain and high fever. In contrast, he developed secondary hypothyroidism with slight enlargement of anterior pituitary gland without relapse of CDI, suggesting of different responses to treatment with interferon $\alpha$ between anterior pituitary lobe and posterior one. So far he continues to be replaced with deficient hormone replacement therapy. As for bone pain, it remains to be controlled with the decreased levels of bone resorption marker with decreased abnormal uptake in bone scintigraphy although zoledronic acid was discontinued for osteonecrosis of the jaw. For four years, he has not showed new involvement at other organs besides bones and the pituitary. While CDI is known to be very common in ECD, improvement of CDI has been reported in a few cases. Other endocrine manifestations, especially with detailed endocrine status, have been also reported in limited cases. Thus we report this case and review the literature.
\end{abstract}

Key words: Erdheim-Chester disease, Hypopituitarism, Diabetes insipidus, Interferon $\alpha$

ERDHEIM-CHESTER DISEASE (ECD) is a rare non-Langerhans cell histiocytosis of unknown etiology, first described in 1930 by William Chester [1]. ECD is characterized by xanthomatous or xanthogranulomatous infiltration of various tissues with a wide range of manifestations, including bone pain, cardiovascular involvement, exophthalmos, central diabetes insipidus (CDI), xanthelasmas, interstitial lung disease, renal failure, central nervous system involvement, bilateral adrenal enlargement, and testis involvement [2].

Although CDI is often mentioned to be a common endocrine manifestation of ECD, other endocrine manifestations are relatively uncommon. Previously Naruse et al. reported about our ECD patient with pitu-

Submitted Oct. 11, 2013; Accepted Nov. 12, 2013 as EJ13-0419 Released online in J-STAGE as advance publication Dec. 3, 2013 Correspondence to: Noriko Makita, Department of Endocrinology and Nephrology, The University of Tokyo School of Medicine, 7-3-1 Hongo, Bunkyo-ku, Tokyo 113-8655 Japan.

E-mail: norimaki-tky@umin.ac.jp itary involvement, focused on the diagnosis [3]. Our patient is atypical in two points in addition to the point of overlapping Langerhans cell infiltration pathologically. First, he was found to have deficiencies of anterior pituitary hormones, as reported previously, accompanied with pituitary swelling. While it is known that ECD often involves central nervous system, there are only a handful of reports in which hypopituitarism due to ECD is investigated endocrinologically in detail. Secondly, his polyuria and polydipsia improved and he became not to need DDAVP three months after the treatment with interferon $\alpha$. It is known that CDI does not tend to ameliorate even if primary disease such as inflammation [4], infiltration [5, 6] or tumor [7, 8], is successfully treated.

Apart from the previous report [3], we focus on his endocrine clinical course and images before and after starting treatment with interferon $\alpha$ and zoledronic acid, accompanied with a review of the literature. 


\section{A Case Report}

A man in his early thirties was admitted to our hospital because of deteriorated fever, fatigue and joint pain. Based on imaging studies, histological findings and his clinical features, he was diagnosed with ECD [3]. Simultaneous endocrine examinations for polyuria, polydipsia, gynecomastia and loss of axillary hair and libido, revealed partial hypopituitarism with extremely low gonadotropins, sex hormones, and vasopressin, as reported previously. In detail, his cortisol level in the early morning was within normal range with elevated level of adrenocorticotropic hormone (ACTH). His prolactin (PRL), thyroid stimulating hormone (TSH), and free thyroxine (free T4) levels were within normal range, but free triiodothyronine (free T3), follicle-stimulating hormone (FSH), luteinizing hormone (LH), free testosterone, growth hormone $(\mathrm{GH})$, and insulin like growth factor 1 (IGF-1) levels were decreased (Table 1).

Pituitary MRI showed thickening of the pituitary stalk, enlargement of the anterior lobe with delayed enhancement and loss of high intensity of the posterior lobe in T1-weighted images (Fig. 1-A1, A2, A3). A hormonal provocative test revealed that the serum cortisol response to $\mathrm{CRH}$ was low in this patient although
Table 1 Laboratory data for the current patient on admission

\begin{tabular}{|c|c|c|c|}
\hline WBC & $16400 / \mu \mathrm{L}$ & u-OSM & $69 \mathrm{mOsm} / \mathrm{kg}$ \\
\hline Seg & $78 \%$ & $\mathrm{u}-\mathrm{Na}$ & $<10 \mathrm{mEq} / \mathrm{L}$ \\
\hline Eosino & $1 \%$ & u-Cre & $16 \mathrm{mg} / \mathrm{dL}$ \\
\hline LYM & $15 \%$ & & \\
\hline $\mathrm{Hb}$ & $12.3 \mathrm{~g} / \mathrm{dL}$ & & \\
\hline Hct & $39.5 \%$ & FPG & $104 \mathrm{mg} / \mathrm{dL}$ \\
\hline PLT & $56 \times 10^{4} / \mu \mathrm{L}$ & HbA1c(JDS) & $6.1 \%$ \\
\hline $\mathrm{TP}$ & $6.8 \mathrm{~g} / \mathrm{dL}$ & & \\
\hline Alb & $3.4 \mathrm{~g} / \mathrm{dL}$ & ACTH & $67 \mathrm{pg} / \mathrm{mL}$ \\
\hline AST & $12 \mathrm{IU} / \mathrm{L}$ & Cortisol & $10 \mu \mathrm{g} / \mathrm{dL}$ \\
\hline ALT & $15 \mathrm{IU} / \mathrm{L}$ & DHEA-S & $196 \mu \mathrm{g} / \mathrm{dL}$ \\
\hline ALP & $226 \mathrm{IU} / \mathrm{L}$ & $\mathrm{GH}$ & $0.054 \mathrm{ng} / \mathrm{mL}$ \\
\hline T-Bil & $0.2 \mathrm{mg} / \mathrm{dL}$ & IGF-1 & $84.4 \mathrm{ng} / \mathrm{mL}$ \\
\hline BUN & $6.8 \mathrm{mg} / \mathrm{dL}$ & $\mathrm{TSH}$ & $1.7 \mu \mathrm{U} / \mathrm{mL}$ \\
\hline Cre & $0.86 \mathrm{mg} / \mathrm{dL}$ & Free T4 & $0.97 \mathrm{ng} / \mathrm{dL}$ \\
\hline $\mathrm{Na}$ & $139 \mathrm{mEq} / \mathrm{L}$ & Free T3 & $3 \mathrm{pg} / \mathrm{mL}$ \\
\hline K & $4.4 \mathrm{mEq} / \mathrm{L}$ & FSH & $1.2 \mathrm{mIU} / \mathrm{mL}$ \\
\hline $\mathrm{Cl}$ & $105 \mathrm{mEq} / \mathrm{L}$ & LH & $0.4 \mathrm{mIU} / \mathrm{mL}$ \\
\hline UA & $7.1 \mathrm{mg} / \mathrm{dL}$ & TST & $0.14 \mathrm{ng} / \mathrm{mL}$ \\
\hline CK & $23 \mathrm{IU} / \mathrm{L}$ & Free TST & $0.7 \mathrm{pg} / \mathrm{mL}$ \\
\hline ferritin & $240 \mathrm{ng} / \mathrm{mL}$ & PRL & $14 \mathrm{ng} / \mathrm{mL}$ \\
\hline CRP & $2.36 \mathrm{mg} / \mathrm{dL}$ & $\mathrm{ADH}$ & $0.3 \mathrm{pg} / \mathrm{mL}$ \\
\hline
\end{tabular}

DHEA-S, dehydroepiandrosterone sulfate; TST, testosterone; $\mathrm{ADH}$, antidiuretic hormone.

Other abbreviations are shown in Appendix.
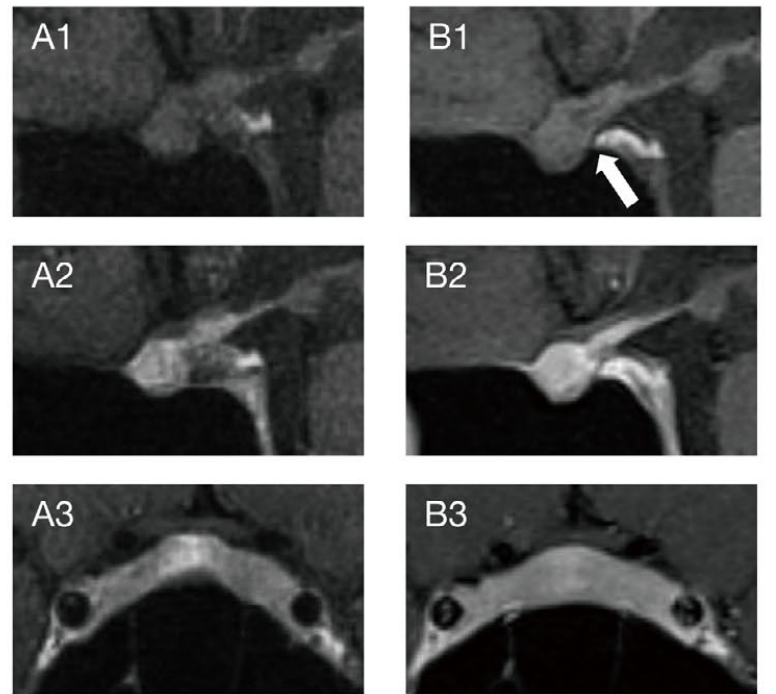
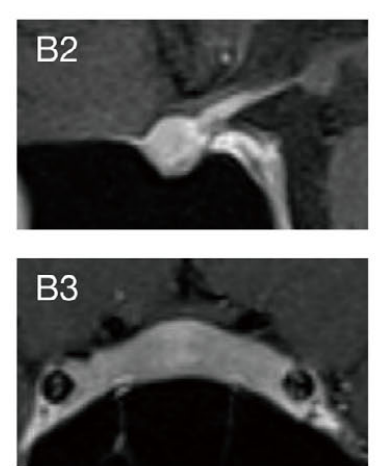
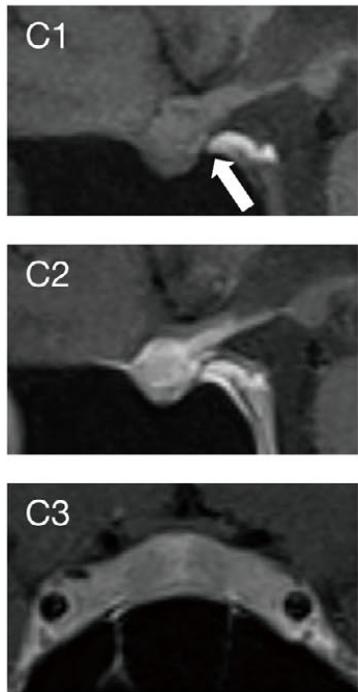
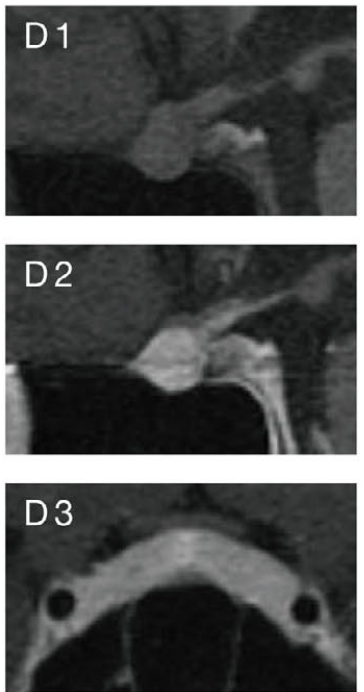

Fig. 1 Sequential pituitary MRIs

Before starting interferon $\alpha$ and zoledronic acid treatment, MRI showed thickening of the pituitary stalk, enlargement of the pituitary gland, and loss of high intensity of the posterior lobe on T1-weighted image (A1, A2, A3). Five months after starting the treatment, the thickening of the pituitary stalk was found to be reduced with slight recovery of high intensity of the posterior lobe in T1-weighted image (B1, B2, B3). One year after starting the treatment, enlargement of the anterior gland was found to be slightly increased with further recovery of high intensity of the posterior lobe in T1-weighted image $(\mathrm{C} 1, \mathrm{C} 2, \mathrm{C} 3)$. One year and six months after starting treatment, there were no particular interval changes except for obscured high intensity of the posterior lobe on T1-weighted image (D1, D2, D3). Arrows indicate slightly recovered high intensity of the posterior lobe on T1-weighted images (B1, C1). 
the basal level of ACTH was found to be high, that the GH response to GRH was low, that the TSH and PRL response to TRH was normal, and that the LH and FSH response to GnRH was low (Table 2). A rapid ACTH infusion test revealed that the serum cortisol response to synthetic ACTH was slightly low (Table 3). The results of a hypertonic saline loading test followed by pitressin infusion were compatible with the presence of CDI (Table 4). For deficit hormones, he started to be replaced with $10 \mathrm{mg}$ hydrocortisone, $2.5 \mu \mathrm{g}$ of 1-desamino-8-D-arginine vasopressin (DDAVP) just before sleep and 5,000 IU hCG three times per week. These replacement therapies improved his manifestations, including nocturia.

For the primary disease showing the severe bone pain and inflammatory reaction with high fever besides pituitary involvement, interferon $\alpha$ [9-12], at a dose of $10^{6}$ IU subcutaneously three times a week, and zoledronic acid $4 \mathrm{mg}$ per one month were started [13] in addition to non-steroid anti-inflammatory drugs and opioids (Fig. 2).

In terms of pituitary involvement, symptoms of polyuria and polydipsia were ameliorated without DDAVP three months after starting the therapies. Subsequent
Table 2 Response of pituitary and adrenal hormones to intravenous injections of CRH $(100 \mu \mathrm{g})$, GRH $(50 \mu \mathrm{g})$, TRH $(500 \mu \mathrm{g})$, and $\mathrm{GnRH}(100 \mu \mathrm{g})$

\begin{tabular}{lcccccc}
\hline Times $(\mathrm{min})$ & 0 & 15 & 30 & 60 & 90 & 120 \\
\hline CRH test & & & & & & \\
ACTH $(\mathrm{pg} / \mathrm{mL})$ & 64 & 99 & 86 & 54 & 34 & 30 \\
$\quad$ Cortisol $(\mu \mathrm{g} / \mathrm{dL})$ & 10.6 & 11.9 & 13.9 & 9.5 & 6.6 & 4.4 \\
GRH test & & & & & & \\
$\quad$ GH $(\mathrm{ng} / \mathrm{mL})$ & 0.006 & 0.233 & 0.391 & 0.392 & 0.164 & 0.066 \\
GnRH test & & & & & & \\
$\quad$ LH $(\mathrm{mIU} / \mathrm{mL})$ & 0.2 & 3.5 & 4.9 & 4.9 & 3 & 3.3 \\
FSH $(\mathrm{mIU} / \mathrm{mL})$ & 1 & 1.8 & 2.4 & 2.7 & 4.1 & 3.1 \\
TRH test & & & & & & \\
$\quad$ TSH $(\mu \mathrm{U} / \mathrm{mL})$ & 1.09 & 13.38 & 15.8 & 11.76 & 7.97 & 5.54 \\
PRL $(\mathrm{ng} / \mathrm{mL})$ & 12 & 25 & 24 & 19 & 16 & 15 \\
\hline
\end{tabular}

Table 3 Response of cortisol to intravenous injection of ACTH $(250 \mu \mathrm{g})$

\begin{tabular}{lccc}
\hline Times $(\mathrm{min})$ & 0 & 30 & 60 \\
\hline Cortisol $(\mu \mathrm{g} / \mathrm{dL})$ & 6.7 & 14.8 & 15.4 \\
\hline
\end{tabular}

Table 4 Hypertonic saline test followed by an infusion of vasopressin

\begin{tabular}{lcccccc}
\hline Times $(\mathrm{min})$ & 0 & 30 & 60 & 90 & 120 iv pitressin \\
\hline Serum Na $(\mathrm{mEq} / \mathrm{L})$ & 143 & 148 & 152 & 153 & 156 & \\
Serum Osm $(\mathrm{mOsm} / \mathrm{kg})$ & 291 & 298 & 305 & 309 & 313 & \\
Urine Osm $(\mathrm{mOsm} / \mathrm{kg})$ & 212 & & 131 & 163 & 227 & 375 \\
ADH $(\mathrm{pg} / \mathrm{mL})$ & 1.08 & 0.44 & 0.35 & 0.46 & 0.39 & \\
\hline
\end{tabular}
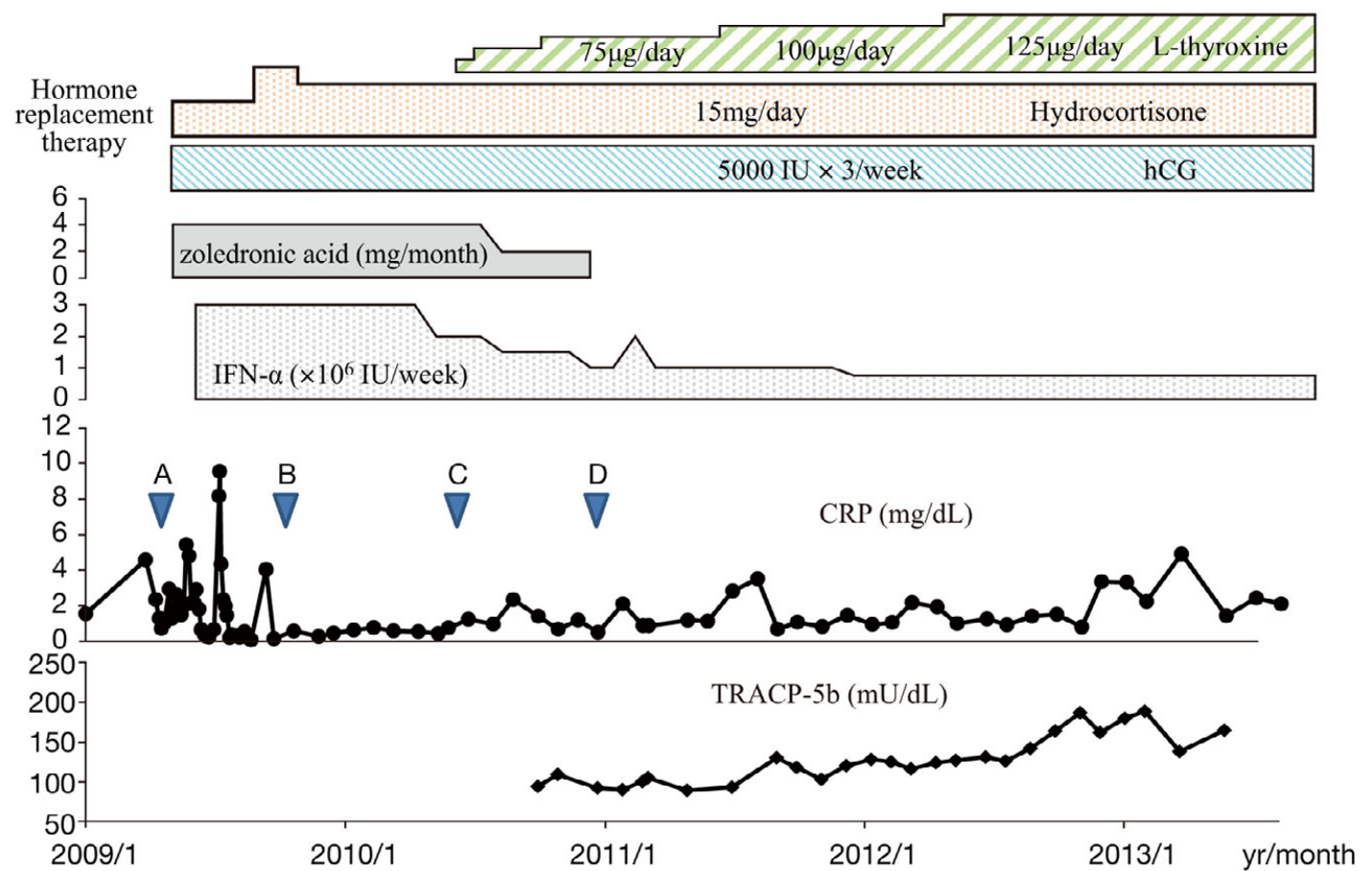

Fig. 2 Temporal profiles of CRP and TRACP-5b levels and treatment of the current patient

Based on a diagnosis of ECD, he was started zoledronic acid ( $4 \mathrm{mg} / \mathrm{month})$ and interferon $\alpha\left(10^{6} \mathrm{IU}\right.$ three times a week) treatment. The levels of TRACP-5b remain to be low although zoledronic acid was discontinued for osteonecrosis of the jaw. The arrowheads A to D correspond to timing of the images with the same capitals in Figs. 1 and 3. 


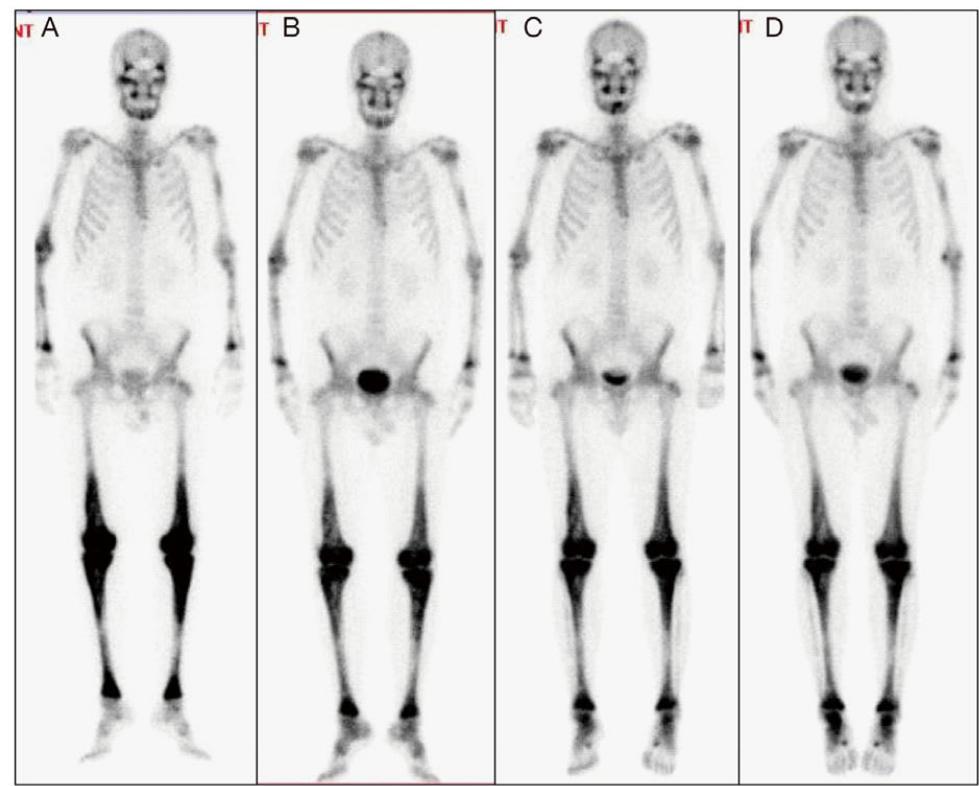

Fig. 3 A bone scintigraphy showed abnormal symmetric accumulation of technetium-99m increased in femora and tibiae before treatment (A). Five months after starting interferon $\alpha$ and zoledronic acid treatment, abnormal uptake in the bones was found to be decreased (B). One year after (C) and one year and six months after (D) starting treatment, abnormal uptake in the bones was unchanged.

MRI showed decreased thickening of the pituitary stalk and slight recover of high intensity of the posterior lobe in T1-weighted image (Fig. 1-B1, B2, B3). A decreased abnormal uptake in technetium-99m bone scintigraphy also supports the effectiveness of his therapy (Fig. 3-A, B). In contrast, one year later after starting the therapies, he needed to start thyroid hormone replacement therapy for secondary hypothyroidism, free $\mathrm{T} 3$ $2.4 \mathrm{pg} / \mathrm{mL}$, free T4 $0.52 \mathrm{ng} / \mathrm{dL}$, TSH $3.12 \mu \mathrm{U} / \mathrm{mL}$. MRI showed slight enlargement of the anterior lobe in spite of further recovery of high intensity of the posterior lobe in T1-weighted image (Fig. 1-C1, C2, C3). One year and six months later after starting the therapies, MRI images did not show any particular interval changes except for obscured high intensity of the posterior lobe on T1-weighted image (Fig. 1-D1, D2, D3). Because there has been no sign of improvement for other pituitary hormones, he continues to be replaced with hydrocortisone and subcutaneous injection of hCG in addition to L-thyroxine without relapse of CDI. GH replacement therapy has been suspended because ECD is regarded as a proliferative disease.

In terms of bone involvement, there has been no sign of flare-up since five months after the therapies (Fig. 3-C, D). Although monthly zoledronic acid was discontinued for osteonecrosis of the jaw bone 18 months later, levels of tartrate-resistant acid phosphatase $5 \mathrm{~b}$
(TRACP-5b) as a bone resorption marker remains to be low for two years. For four years, he has not showed any evidence of new involvement at other organs besides bones and the pituitary.

\section{Discussion}

Erdheim-Chester disease is a rare non-Langerhans form of histiocytosis, characterized by multi-systemic xanthogranulomatous infiltration. To date about 500 cases have been reported in the literature [14]. The disease commonly affects the skeleton, but can involve the central nervous system, orbits, retroperitoneum, skin, and viscera such as heart, lung, liver and kidney. We experienced a unique ECD patient who presented with deficiencies in anterior pituitary hormones (hypopituitarism) besides CDI, which is known to be as one of the most common manifestations in ECD.

\section{Hypopituitarism in ECD}

As for CDI, a review of the published literatures showed that CDI was documented in 53 of 110 patients with ECD [15]. It has been reported that approximately one-quarter of the patients of ECD developed CDI, caused by infiltration of the pituitary gland $[2,14]$. In contrast, deficiencies in anterior pituitary hormones have been described in limited numbers of cases (Table 5). 
Table 5 Cases of hypopituitarism with ECD reported in the literature

\begin{tabular}{|c|c|c|c|c|c|c|c|c|c|c|c|}
\hline No & age & sex & $\begin{array}{l}\text { impaired } \\
\text { hormones }\end{array}$ & PRL & DI & bone & $\begin{array}{l}\text { findings of images or } \\
\text { pathology }\end{array}$ & pituitary stimulation test & therapy & outcome & Reference \\
\hline 1 & 44 & M & Gn, TST & Normal & + & +1 & No abnormity (CT) & $\begin{array}{l}\text { Cortisol and GH responses to ITT } \\
\text { were normal. }\end{array}$ & $\begin{array}{l}\text { Prednisone + } \\
\text { vinblastine -> } \\
\text { radiation }\end{array}$ & $\begin{array}{l}\text { Not effective } \\
\text { except radiation }\end{array}$ & [24] \\
\hline 2 & 30 & M & GH, Gn, TST & Normal & + & + & $\begin{array}{l}\text { Thickened pituitary stalk (CT/ } \\
\text { MRI), Partially empty sella } \\
\text { (CT) }\end{array}$ & $\begin{array}{l}\text { Cortisol response to ITT was } \\
\text { normal. } \\
\text { GH responses to ITT and } \\
\text { L-Dopamin were low. } \\
\text { TSH and PRL responses to TRH } \\
\text { were normal. }\end{array}$ & NR & NR & [25] \\
\hline 3 & 7 & M & IGF-1 & Elevated & + & +1 & NR & $\begin{array}{l}\text { PRL showed hyper response to } \\
\text { TRH. } \\
\text { TSH response to TRH and } \\
\text { Cortisol responses to } \\
\text { hypoglycemia and a metyrapone } \\
\text { test were normal }\end{array}$ & $\begin{array}{l}\text { Hormone } \\
\text { replacement }\end{array}$ & Stable (2.5 years) & [16] \\
\hline 4 & 58 & $\mathrm{~F}$ & IGF-1, Gn & Elevated & + & +1 & $\begin{array}{l}\text { Loss of T1-high intensity in } \\
\text { posterior lobe (MRI) }\end{array}$ & $\begin{array}{l}\text { Gn response to } \mathrm{GnRH} \text { was } \\
\text { normal. }\end{array}$ & $\begin{array}{l}\text { Steroid for } 6 \\
\text { months }\end{array}$ & Not effective (die) & [17] \\
\hline 5 & 55 & M & $\begin{array}{l}\text { ACTH, T4, GH, } \\
\text { Gn, TST }\end{array}$ & Elevated & + & $+s$ & Suprasellar mass (MRI) & NR & $\begin{array}{l}\text { Hormone } \\
\text { replacement }\end{array}$ & $\begin{array}{l}\text { Stable except } \\
\text { meninges ( } 8 \text { years) }\end{array}$ & [18] \\
\hline 6 & 46 & $\mathrm{M}$ & Gn, TST & Normal & + & +1 & Normal (MRI) & NR & $\begin{array}{l}\text { Predonisolone + } \\
\text { indomethacin -> } \\
\text { azathioprine }+ \\
\text { vinblastine }\end{array}$ & $\begin{array}{l}\text { Effective } \\
\text { (bone pain) }\end{array}$ & [26] \\
\hline 7 & 51 & M & Gn, Cortisol & NR & + & - & $\begin{array}{l}\text { Intra- and suprasellar mass } \\
\text { (MRI) } \\
\text { A xanthogranulomatous lesion } \\
\text { composed of CD68(+) foam } \\
\text { cells and Touton-like giant cells } \\
\text { (hypophyseal mass) }\end{array}$ & $\begin{array}{l}\text { GnRH, CRH, and TRH infusion } \\
\text { test comfirrmed a complete } \\
\text { sexual hormone and an } \\
\text { incomplete cortisol deficiency. }\end{array}$ & NR & NR & [33] \\
\hline
\end{tabular}

847 M Gn, GH $\quad$ Elevated $-\quad+\underset{\text { Enlargement of the pituitary }}{(\text { MRI })}$

\begin{tabular}{|c|c|c|c|c|c|c|c|c|c|c|c|}
\hline 9 & 35 & $\mathrm{~F}$ & TSH, T4, Cortisol & NR & + & + & $\begin{array}{l}\text { Intact anterior pituitary lobe } \\
\text { Destruction of posterior } \\
\text { pituitary lobe and pituitary } \\
\text { stalk (autopsy) }\end{array}$ & NR & $\begin{array}{l}\text { Cytostatic agents, } \\
\text { radiation, } \\
\text { glucocorticoids }\end{array}$ & Not effective (die) & [23] \\
\hline 10 & 54 & $\mathrm{~F}$ & Gn, TST & NR & + & + & Retroorbital mass (MRI) & NR & NR & NR & [31] \\
\hline 11 & 50 & M & $\begin{array}{l}\text { Gn, TST, (Cortisol, } \\
\text { T4)* }\end{array}$ & NR & NR & + & $\begin{array}{l}\text { A xanthogranulomatous } \\
\text { lesion composed of CD68(+) } \\
\text { S100(-) foam cells and Touton- } \\
\text { like giant cells (biopsy from } \\
\text { pituitary) }\end{array}$ & NR & $\begin{array}{l}\text { Stenting of bile } \\
\text { duct }\end{array}$ & Effective (7 years) & [34] \\
\hline 12 & 43 & M & Gn, TST, T4, IGF-1 & Normal & + & + & $\begin{array}{l}\text { Suprasellar mass, involving } \\
\text { upper pituitary stalk and } \\
\text { hypothalamus (MRI) }\end{array}$ & NR & IFN- $\alpha$ & Stable (6 months) & [20] \\
\hline 13 & 26 & $\mathrm{~F}$ & Panhypopituitarism & NR & + & - & Suprasellar mass (MRI) & NR & $\begin{array}{l}\text { Operation, } \\
\text { radiation }\end{array}$ & Not effective (die) & [21] \\
\hline 14 & 32 & $\mathrm{~F}$ & Panhypopituitarism & NR & + & + & Suprasellar mass (MRI) & NR & IFN- $\alpha$ & Stable (over 1 year) & [22] \\
\hline 15 & 31 & $\mathrm{~F}$ & Gn, TST & NR & + & + & NR & NR & IFN- $\alpha$ & Stable (1.5 years) & [32] \\
\hline & $\begin{array}{l}\text { early } \\
30 \mathrm{~s}\end{array}$ & $\mathrm{M}$ & $\begin{array}{l}\text { Gn, TST, ACTH, } \\
\text { Cortisol, GH, IGF-1 } \\
\text { (TSH, free T4, free } \\
\text { T3) }\end{array}$ & Normal & + & + & $\begin{array}{l}\text { Thickened pituitary stalk and } \\
\text { enlarged anterior lobe with } \\
\text { delayed enhancement (MRI) }\end{array}$ & $\begin{array}{l}\text { Cortisol response to CRH was } \\
\text { low. } \\
\text { GH response to GRH was low. } \\
\text { TSH and PRL responses to TRH } \\
\text { were normal. } \\
\text { LH and FSH responses to GnRH } \\
\text { were low. }\end{array}$ & $\begin{array}{l}\text { IFN- } \alpha \\
\text { zoledronic acid }\end{array}$ & Stable (4 years) & $\begin{array}{c}\text { Our } \\
\text { patient }\end{array}$ \\
\hline
\end{tabular}

Age, age at diagnosis; M, male; F, female; bone, skeletal manifestations; ITT, insulin tolerance test; Gn, gonadotropin; TST, testosterone; NR, not reported; IFN- $\alpha$, interferon- $\alpha ;{ }^{*}$, After transcranial micro-surgical extirpation of a hormonally inactive pituitary lesion

infusion test: LH, FSH, ACTH, cortisol, and TRH showed adequate responses. GH showed

Predonisolone Stable (6 months)

low.

$\mathrm{LH}$ and FSH responses to GnRH

ur

GnRH, CRH, TRH, and GHRH

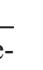


Hypopituitarism can result from diseases of pituitary gland, pituitary stalk, and hypothalamus. Disorder at the level of hypothalamus leads to decreased production and secretion of stimulatory hormones such as $\mathrm{CRH}, \mathrm{TRH}, \mathrm{GRH}$ and GnRH, and of inhibitory hormones such as dopamine. Disorder at the level of pituitary stalk leads to disturbance of delivery of those hormones through hypophyseal portal system. Both disorders may lead to decreased secretion of ACTH, GH, $\mathrm{LH}, \mathrm{FSH}$ and TSH, and to increased secretion of PRL from anterior pituitary, suggesting that increased level of PRL is a hallmark of disorder at the level of hypothalamus or stalk.

In the reported ECD cases showing hypopituitarism, 3 of 16 cases were described as having panhypopituitarism (Table 5). Among the remaining 13 cases, 11 cases had hypogonadotropic hypogonadism, 6 cases had GH deficiency, 4 cases had ACTH deficiency, and 4 cases had secondary hypothyroidism. Most of 16 cases showed supraseller mass and/or elevated level of PRL, indicating that they had disorders at the level of pituitary stalk or hypothalamus (Table 5). In detail, case 3 [16], 4 [17], 5 [18] and 8 [19] showed increased level of PRL. Among them, case 3 showed increased responses of PRL to TRH, and case 4 and 8 showed adequate responses of gonadotropin to $\mathrm{GnRH}$ in spite of showing hypogonadotropic hypogonadism, supporting the presence of suprasellar dysfunction. Case 12 [20], 13 [21] and 14 [22] as well as case 5 showed suprasellar mass in MRIs, suggesting that their hypopituitarism is due to suprasellar dysfunction. In fact, in case 9 [23], autopsy proved that the anterior lobe was intact and the posterior lobe was completely replaced by xanthogranulomatous infiltrates.

In contrast, 4 cases (case 1 [24], 2 [25], 6 [26] and 12) showed anterior pituitary hormone deficiency with normal level of PRL. However, not to mention the image of case 12, the image of case 2 showing thickened stalk and partially empty sella supports suprasellar damage despite of normal level of PRL. Case 1 and 6 with normal level of PRL showed hypogonadotropic hypogonadism without abnormalities in CT or MRI. In the cases of hypopituitarism caused by pituitary mass [27, 28] or apoplexy [29, 30], gonadotropin is known as one of the pituitary hormones that are impaired early. However, case 1 and 6 showed no abnormalities in the images, supporting the possibility that they might not have shown structural disorder due to xanthogranulomatous infiltration, but might have shown functional disorder due to systemic severe illness, accompanied with high fever and high level of CRP. Similarly, case 10 [31] and 15 [32] might have shown functional hypogonadotropic hypogonadism. As seen in case 7 [33] and 11 [34], intrasellar pituitary xanthogranulomatous infiltration in the resected specimen suggests that hypopituitarism might be caused by the direct damage of anterior pituitary. However, basal PRL level is not available in these cases.

Based on the discussion above, our case (case 16) is atypical. He showed normal level of basal PRL and normal response to intravenous TRH, suggesting that the hypothalamic-pituitary portal system was still working. The other results of loading tests, revealing low reactions of ACTH and cortisol to $\mathrm{CRH}, \mathrm{GH}$ to GRH and LH and FSH to GnRH, are compatible with damage at the pituitary level. MRIs showing involvement of anterior lobe and clinical improvement of CDI with interferon therapy are also supporting that the disorder of the anterior pituitary gland was the main cause of anterior pituitary hormone deficiency in our patient.

In summary, most reported cases of hypopituitarism in ECD had suprasellar mass or elevated basal PRL levels, indicating that they had disorders of the pituitary stalk or hypothalamus. In contrast, there are few cases in which the disorder of anterior pituitary gland itself seems to be the main cause of anterior pituitary hormone deficiency in ECD. From this point of view, we think that our case is valuable to report as a rare case.

\section{Hypothalamic-pituitary imaging in ECD}

Apart from the view of functional status of hypothalamic-infundibulo-pituitary axis, there is a report investigating the brain images in ECD patients [35]. In this report, it has been reported that hypothalamic-pituitary axis was involved in $16(47 \%)$ of 33 ECD patients, most frequently, 14 showed loss of T1-high intensity at posterior lobe and 6 showed thickened stalk. In contrast, it did not mention about the anterior lobe or intrasellar involvement besides the loss of T1-high intensity of the posterior lobe. Some among the 6 patients showing thickened stalk might have shown hypopituitarism although they had not been evaluated from the point of hormonal status. In contrast, cardiovascular and central nervous system involvements have been well investigated in the point of fatalness. In fact, it has been reported that cardiovascular involvement is a major cause of death [36] and that CNS involvement is the independent clinical predictor of poor survival [11] 
in ECD. It is possible that hypopituitarism besides CDI would be evident in more patients than it was reported (Table 5). It is to be seen whether hypopituitarism in $\mathrm{ECD}$ is really rare or not.

\section{Treatment and outcome of hypopituitarism and CDI in ECD}

For ECD, no standard treatment has been available and no case of cure has been reported so far. It has been reported that ECD patients were treated with glucocorticoids and/or cytotoxic agents in addition to radiation and operation $[14,37]$, but the efficacy is still to debate. Interferon $\alpha$ has been used since the report of success in the treatment of ECD [9]. However, the efficacy seems to vary depending on patients and the sites of disease involvement, and it may not be effective for central nervous system and cardiovascular involvement [10]. However, recent multicenter analysis of 53 patients showed treatment with interferon $\alpha$ is as an independent predictor of survival [11].

In terms of the function of posterior lobe, there have been few reports of improvement in CDI with therapy, although improvement of pituitary involvement in the images has been reported in some cases $[10,12]$. For example, although 2 of 7 cases with the pituitary involvement improved in the images with long-term high dose interferon $\alpha$ [12], they were not referred to hormonal improvement. Braiteh and colleagues [9] firstly reported that 2 of 3 ECD patients treated with interferon $\alpha$ showed gradual improvement in CDI. Since then, however, there is no other report referring to outcome of CDI in ECD with the treatment of interferon $\alpha$. Our current patient improved in symptoms of CDI without DDAVP, accompanied with decreased thickening of pituitary stalk after treatment for several months. Considering CDI, especially in children and young adults, is caused by destruction or degeneration of the neurons that originate in the supraoptic and paraventricular nuclei of the hypothalamus [38] and does not tend to ameliorate even if primary disease such as inflammation, infiltration or tumor is successfully treated, our case is unique.

In terms of the function of anterior lobe, there have been very few reports. Interestingly, our patient developed secondary hypothyroidism while sign and symptom of CDI disappeared without DDAVP. Interferon $\alpha$ often causes thyroid dysfunction due to autoimmune thyroid disease such as destructive thyroiditis, chronic thyroiditis and Graves' disease. Furthermore it has been reported that interferon $\alpha$ shows direct inhibitory effects on thyroid hormone synthesis, release, and metabolism [39]. In contrast, several cases of hypopituitarism with no abnormality or a small cyst in MRIs have been reported in patients with chronic hepatitis virus infection undergoing interferon $\alpha$ treatment [40]. In our case, however, his thyroid dysfunction, secondary hypothyroidism, was more likely caused by pituitary involvement of ECD rather than by interferon $\alpha$ treatment, considering of slightly progressive enlargement of the pituitary gland in MRI (Fig. 1-C1, C2, C3), pre-existing deficiencies in other pituitary hormones, and no improvement in thyroid dysfunction in spite of dose reduction of interferon $\alpha$.

To be summarized, he showed different responses to treatment with interferon $\alpha$ between anterior pituitary lobe and posterior one. What mechanism caused this discrepancy of treatment effects? A hint might be in the point that bone specimen showed overlapping Langerhans cell infiltration histologically although there was no evidence in pituitary specimen. If Langerhans cells dominantly infiltrate anterior lobe and non-Langerhans cells dominantly posterior lobe and pituitary stalk, his unique clinical course showing secondary hypothyroidism with enlargement of anterior lobe and improvement of CDI with decreased thickening of pituitary stalk after starting interferon $\alpha$ treatment is interpretable. That's because anterior pituitary dysfunction is found in up to $20 \%$ of patients with Langerhans cell histiocytosis (LCH) [41], interferon $\alpha$ treatment is not considered as effective approach for $\mathrm{LCH}$, and established DI in LCH is generally permanent [41, 42], based on previous reports. The point that our patient is in early adulthood is also compatible with overlapping LCH [43-45].

\section{Other endocrine involvement in ECD}

Besides hypothalamic-pituitary involvement, enlargement of adrenal glands has been reported in some case reports [17] and 7 of the 22 patients [46]. Infiltration of thyroid $[47,48]$, pancreas $[49,50]$ and testis $[48$, 51] has been reported in rare cases. For our patient, no other involvement besides bone and infundibulo-pituitary is evident from the images of whole body CT and FDG-PET.

\section{Zoledronic acid for ECD}

Bisphosphonates have been used for bone lesions of ECD causing bone pain and microfracture by target- 
ing for osteoclasts [13, 52-57]. In fact, it was reported that ECD patients treated with zoledronic acid, pamidronate, or alendronate showed significant relief of bone pain $[13,55,57]$ and biochemical marker of bone turnover [54], homologous to patients with bone metastatic lesions of malignant tumor [58]. As for our patient, treatment with interferon $\alpha$ and monthly zoledronic acid relieved bone pain with decreased level of CRP. Although zoledronic acid was discontinued for osteonecrosis of the jaw bone 18 months later, his bone pain has been controlled with low level of TRACP-5b for the subsequent two years. It might be attributed to the effect of regularly administered interferon $\alpha$, However, considering the reports showing that zoledronic acid can be found in bone, soft tissue, and plasma 8 months after injection and that a single infusion of zoledronic acid produces sustained effect beyond a year [59], the prolonged effect of zoledronic acid in our patient may be attributed to its accumulation in the bone matrix.

Pro-inflammatory cytokines, such as interleukin- $1 \alpha$ (IL- $1 \alpha$ ), tumor necrosis factor $\alpha$ (TNF- $\alpha$ ) and IL-6, were reported to be strongly expressed in the foamy macrophages of ECD [31]. These cytokines released by the foamy macrophages can stimulate osteoclast activity, and bisphosphonate can play a role in inhibiting the activity. In addition to these cytokines, receptor activator of NF-kappaB ligand (RANKL) was reported to be expressed in the foamy macrophages of bone lesion $(53 \%)$ and lung (15\%) [31]. If this is the case, administration of anti-RANKL antibody might be a therapeutic option in our patient, by targeting not only to osteoclast but also the foamy macrophages when skeletal manifestations flare up again.

In summary, we report a patient of ECD with pituitary involvement, focusing on endocrine clinical course and images before and after treatment, especially CDI and anterior pituitary hormone deficiencies with MRIs. He showed different responses to treatment with interferon $\alpha$ between anterior pituitary lobe and posterior one. We thus think it is important to assess and follow endocrine status in addition to imaging studies in ECD patients with pituitary involvement.

\section{Disclosure}

None of the authors have any potential conflicts of interest associated with this research.

\section{Appendix}

WBC, white blood cell; Seg, segmented cell; Eosino, eosinophile; LYM, lymphocyte; Hb, hemoglobin; Hct, hematocrit; PLT, platelet; TP, total protein; Alb, albumin; AST, aspartate aminotransferase; ALT, alanine aminotransferase; ALP, alkaline phosphatase; T-Bil, total bilirubin; BUN, blood urea nitrogen; Cre, creatinine; $\mathrm{Na}$, sodium; $\mathrm{K}$, potassium; $\mathrm{Cl}$, chloride; $\mathrm{UA}$, uric acid; $\mathrm{CPK}$, creatine phosphokinase; CRP, C-reactive protein; s-OSM, serum osmolarity; u-OSM, urine osmolarity; u-Na, urine sodium; u-Cre, urine creatinine; FPG, fasting plasma glucose; HbA1c (JDS), hemoglobin A1c (Japan Diabetes Society)

\section{References}

1. Chester W (1930) Über lipoidgranulomatose. Virchows Archiv 279: 561-602.

2. Haroche J, Arnaud L, Amoura Z (2012) ErdheimChester disease. Curr Opin Rheumatol 24: 53-59.

3. Naruse H, Shoda H, Okamoto A, Oka T, Yamamoto K (2010) A case of osteoarthropathy due to ErdheimChester disease with overlapping Langerhans' cell infiltration. Intern Med 49: 1225-1228.

4. Caturegli P, Newschaffer C, Olivi A, Pomper MG, Burger PC, et al. (2005) Autoimmune hypophysitis. Endocr Rev 26: 599-614.

5. Arico M, Girschikofsky M, Genereau T, Klersy C, McClain K, et al. (2003) Langerhans cell histiocytosis in adultsReport from the International Registry of the Histiocyte Society. Eur J Cancer 39: 2341-2348.
6. Tabuena RP, Nagai S, Handa T, Shigematsu M, Hamada $\mathrm{K}$, et al. (2004) Diabetes insipidus from neurosarcoidosis: long-term follow-up for more than eight years. Intern Med 43: 960-966.

7. Aida T, Abe H, Fujieda K, Matsuura N (1993) Endocrine functions in children with suprasellar germinoma. Neurol Med Chir (Tokyo) 33: 152-157.

8. Eguchi K, Uozumi T, Arita K, Kurisu K, Yano T, et al. (1994) Pituitary function in patients with Rathke's cleft cyst: significance of surgical management. Endocr J 41: 535-540.

9. Braiteh F, Boxrud C, Esmaeli B, Kurzrock R (2005) Successful treatment of Erdheim-Chester disease, a non-Langerhans-cell histiocytosis, with interferon-alpha. Blood 106: 2992-2994. 
10. Haroche J, Amoura Z, Trad SG, Wechsler B, Cluzel P, et al. (2006) Variability in the efficacy of interferon-alpha in Erdheim-Chester disease by patient and site of involvement: results in eight patients. Arthritis Rheum 54: 3330-3336.

11. Arnaud L, Hervier B, Neel A, Hamidou MA, Kahn JE, et al. (2011) CNS involvement and treatment with interferon-alpha are independent prognostic factors in Erdheim-Chester disease: a multicenter survival analysis of 53 patients. Blood 117: 2778-2782.

12. Hervier B, Arnaud L, Charlotte F, Wechsler B, Piette JC, et al. (2012) Treatment of Erdheim-Chester disease with long-term high-dose interferon-alpha. Semin Arthritis Rheum 41: 907-913.

13. Srikulmontree T, Massey HD, Roberts WN (2007) Treatment of skeletal Erdheim-Chester disease with zoledronic acid: case report and proposed mechanisms of action. Rheumatol Int 27: 303-307.

14. Haroche J, Arnaud L, Cohen-Aubart F, Hervier B, Charlotte F, et al. (2013) Erdheim-Chester disease. Rheum Dis Clin North Am 39: 299-311.

15. Brodkin CL, Wszolek ZK (2006) Neurologic presentation of Erdheim-Chester disease. Neurol Neurochir Pol 40: 397-403.

16. Globerman H, Burstein S, Girardina PJ, Winchester P, Frankel S (1991) A xanthogranulomatous histiocytosis in a child presenting with short stature. $J$ Pediatr Hematol Oncol 13: 42-46.

17. Tritos NA, Weinrib S, Kaye TB (1998) Endocrine manifestations of Erdheim-Chester disease (a distinct form of histiocytosis). J Intern Med 244: 529-535.

18. Oweity T, Scheithauer BW, Ching HS, Lei C, Wong KP (2002) Multiple system Erdheim-Chester disease with massive hypothalamic-sellar involvement and hypopituitarism. J Neurosurg 96: 344-351.

19. Perras B, Petersen D, Lorch H, Fehm H (2002) Psychoneuroendocrine disturbances in a patient with a rare granulomatous disease. Exp Clin Endocrinol Diabetes 110: 248-252.

20. Cabot RC, Harris NL, Shepard J-AO, Rosenberg ES, Cort AM, et al. (2008) Case 25-2008: A 43-year-old man with fatigue and lesions in the pituitary and cerebellum. $N$ Engl J Med 359: 736-747.

21. Abla AA, Wilson DA, Eschbacher JM, Spetzler RF (2010) Neurosurgical biopsy as the initial diagnosis of xanthogranuloma of the Erdheim-Chester disease variety of the infundibulum and optic apparatus: letter to the editor. Acta Neurochir (Wien) 152: 925-927.

22. Pineles SL, Liu GT, Acebes X, Arruga J, Nasta S, et al. (2011) Presence of Erdheim-Chester disease and Langerhans cell histiocytosis in the same patient: a report of 2 cases. J Neuroophthalmol 31: 217-223.

23. Kovacs K, Bilbao JM, Fornasier VL, Horvath E (2004) Pituitary pathology in Erdheim-Chester disease. Endocr Pathol 15: 159-166.
24. Miller RL, Sheeler LR, Bauer TW, Bukowski RM (1986) Erdheim-Chester disease. Case report and review of the literature. Am J Med 80: 1230-1236.

25. Tien R, Kucharczyk J, Newton TH, Citron JT, Duffy TJ (1990) MR of diabetes insipidus in a patient with Erdheim-Chester disease: case report. AJNR Am J Neuroradiol 11: 1267-1270.

26. Khamseh ME, Mollanai S, Hashemi F, Rezaizadeh A, Azizi F (2002) Erdheim-Chester syndrome, presenting as hypogonadotropic hypogonadism and diabetes insipidus. J Endocrinol Invest 25: 727-729.

27. Ferrante E, Ferraroni M, Castrignanò T, Menicatti L, Anagni M, et al. (2006) Non-functioning pituitary adenoma database: a useful resource to improve the clinical management of pituitary tumors. Eur J Endocrinol 155: 823-829.

28. Valassi E, Biller BM, Klibanski A, Swearingen B (2010) Clinical features of nonpituitary sellar lesions in a large surgical series. Clin Endocrinol (Oxf) 73: 798-807.

29. Sert M, Tetiker T, Kirim S, Kocak M (2003) Clinical report of 28 patients with Sheehan's syndrome. Endocr J 50: 297-301.

30. Lubina A, Olchovsky D, Berezin M, Ram Z, Hadani M, et al. (2005) Management of pituitary apoplexy: clinical experience with 40 patients. Acta Neurochir (Wien) 147: 151-157.

31. Stoppacciaro A, Ferrarini M, Salmaggi C, Colarossi C, Praderio L, et al. (2006) Immunohistochemical evidence of a cytokine and chemokine network in three patients with Erdheim-Chester disease: implications for pathogenesis. Arthritis Rheum 54: 4018-4022.

32. Tzoulis C, Gjerde IO, Softeland E, Neckelmann G, Strom E, et al. (2012) Erdheim-Chester disease presenting with an intramedullary spinal cord lesion. J Neurol 259: 2240-2242.

33. Reithmeier T, Trost HA, Wolf S, Stolzle A, Feiden W, et al. (2002) Xanthogranuloma of the ErdheimChester type within the sellar region: case report. Clin Neuropathol 21: 24-28.

34. Gundling F, Nerlich A, Heitland WU, Schepp W (2007) Biliary manifestation of Erdheim-Chester disease mimicking Klatskin's carcinoma. Am J Gastroenterol 102: 452-454.

35. Drier A, Haroche J, Savatovsky J, Godeneche G, Dormont D, et al. (2010) Cerebral, facial, and orbital involvement in Erdheim-Chester disease: CT and MR imaging findings. Radiology 255: 586-594.

36. Haroche J, Amoura Z, Dion E, Wechsler B, CostedoatChalumeau N, et al. (2004) Cardiovascular involvement, an overlooked feature of Erdheim-Chester disease: report of 6 new cases and a literature review. Medicine (Baltimore) 83: 371-392.

37. Mazor RD, Manevich-Mazor M, Shoenfeld Y (2013) Strategies and treatment alternatives in the management of Erdheim-Chester disease. Expert Opin Orphan 
Drugs 1: 891-899.

38. Maghnie M (2004) Diabetes insipidus. Horm Res 59 Suppl 1: 42-54.

39. Carella C, Mazziotti G, Amato G, Braverman L, Roti E (2004) Interferon- $\alpha$-related thyroid disease: Pathophysiological, epidemiological, and clinical aspects. J Clin Endocrinol Metab 89: 3656-3661.

40. Tran HA, Crock PA, Reeves GE (2012) Pituitary Disease in Chronic Hepatitis C Infection and Interferonalpha Related Therapy: Two Case Reports. J Endocrinol Metab 2: 190-194.

41. Makras P, Alexandraki KI, Chrousos GP, Grossman AB, Kaltsas GA (2007) Endocrine manifestations in Langerhans cell histiocytosis. Trends Endocrinol Metab 18: 252-257.

42. Fahrner B, Prosch H, Minkov M, Krischmann M, Gadner H, et al. (2012) Long-term outcome of hypothalamic pituitary tumors in Langerhans cell histiocytosis. Pediatr Blood Cancer 58: 606-610.

43. Aouba A, Larousserie F, Le Guern V, Martin A, Guillevin L (2009) Spumous histiocytic oligoarthritis coexisting with systemic Langerhans' cell histiocytosis: case report and literature review. Joint Bone Spine 76: 701-704.

44. Cabot RC, Scully RE, Mark EJ, McNeely WF, Ebeling SH, et al. (2000) Case 9-2000: A 41-Year-Old Man with Multiple Bony Lesions and Adjacent Soft-Tissue Masses. N Engl J Med 342: 875-883.

45. Andrade V, Nemer C, Prezotti A, Goulart W (2004) Erdheim-Chester disease of the breast associated with Langerhans-cell histiocytosis of the hard palate. Virchows Archiv 445: 405-409.

46. Haroche J, Amoura Z, Touraine P, Seilhean D, Graef C, et al. (2007) Bilateral adrenal infiltration in ErdheimChester disease. Report of seven cases and literature review. J Clin Endocrinol Metab 92: 2007-2012.

47. Schmidt HH, Gregg RE, Shamburek R, Brewer BH, Jr., Zech LA (1997) Erdheim-Chester disease: low low-density lipoprotein levels due to rapid catabolism. Metabolism 46: 1215-1219.

48. Sheu SY, Wenzel RR, Kersting C, Merten R, Otterbach F, et al. (2004) Erdheim-Chester disease: case report with multisystemic manifestations including testes, thyroid, and lymph nodes, and a review of literature. J Clin
Pathol 57: 1225-1228.

49. Poehling GG, Adair DM, Haupt HA (1984) ErdheimChester disease. A case report. Clin Orthop Relat Res 185: 241-244.

50. Lachenal F, Cotton F, Desmurs-Clavel H, Haroche J, Taillia H, et al. (2006) Neurological manifestations and neuroradiological presentation of Erdheim-Chester disease: report of 6 cases and systematic review of the literature. J Neurol 253: 1267-1277.

51. Bancroft LW, Berquist TH (1998) Erdheim-Chester disease: radiographic findings in five patients. Skeletal Radiol 27: 127-132.

52. Mossetti G, Rendina D, Numis F, Somma P, Postiglione L, et al. (2003) Biochemical markers of bone turnover, serum levels of interleukin-6/interleukin-6 soluble receptor and bisphosphonate treatment in ErdheimChester disease. Clin Exp Rheumatol 21: 232-236.

53. Jendro MC, Zeidler H, Rosenthal H, Haller H, Schwarz A (2004) Improvement of Erdheim-Chester disease in two patients by sequential treatment with vinblastine and mycophenolate mofetil. Clin Rheumatol 23: 52-56.

54. Eyigör S, Kirazlı Y, Memis A, Başdemir G (2005) Erdheim-Chester disease: the effect of bisphosphonate treatment - a case report. Arch Phys Med Rehabil 86: 1053-1057.

55. Altinel L, Degirmenci B, Kose KC, Sahin O, Ergan V (2008) Erdheim-Chester disease. Joint Dis Rel Surg 19: 140-143.

56. de Abreu MR, Castro MO, Chung C, Trudell D, Biswal S, et al. (2009) Erdheim-Chester disease: case report with unique postmortem magnetic resonance imaging, high-resolution radiography, and pathologic correlation. Clin Imaging 33: 150-153.

57. Mounach A, Nouijai A, Achemlal L, El Maghraoui A, Bezza A (2010) Erdheim-Chester disease: a case report with pulmonary, kidney involvement and bone lesions. Rheumatol Int 30: 651-654.

58. Saad F (2008) New research findings on zoledronic acid: survival, pain, and anti-tumour effects. Cancer Treat Rev 34: 183-192.

59. Russell R, Watts N, Ebetino F, Rogers M (2008) Mechanisms of action of bisphosphonates: similarities and differences and their potential influence on clinical efficacy. Osteoporos Int 19: 733-759. 